represented by phenomena occurring in the Ozark Plateau region, the particular portion of it included in this epoch is no better demarked than in the coastal plain. But the Ozark region immediately adjoins a driftcovered region on which the Kansan drift sheet is widely exposed, and when the two regions have been exhaustively studied the relation of the drift to the valleys along the border will furnish data for discriminating the proposed Ozarkian epoch from that which followed. The geographical element of the term has been already used in geological nomenclature, as, for example, the Ozark Series, the Ozark Uplift and the Ozark Plateau, but the term as suggested differs so widely from those in use that it can never be confounded with them. Furthermore, the term is euphonious and in harmony with the nomenclature already adopted for the other epochs of the Pleistocene period.

The Ozarkian epoch as here proposed may be defined as a marked period of elevation and sub-aërial erosion instituted by the great post-Tertiary epeirogenic uplift of North America, and terminated by the Kansan epoch of widely extended glaciation. The following general table of the sub-divisions of the Quaternary Era graphically exemplifies its relative position :

\begin{tabular}{|c|c|c|}
\hline & 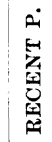 & $\begin{array}{l}\text { PRESENT EPOCH.......DEPOSITION. } \\
\text { TERRACE EPOCH.......EROSION. }\end{array}$ \\
\hline 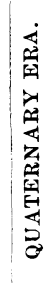 & 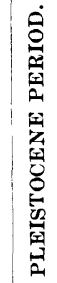 & $\begin{array}{l}\text { Wisconsin Epoch...3d Glacial......... Drift. } \\
\text { Toronto ? Epoch.....2d inter-Glacial...Erosion. } \\
\text { Iowan Epoch.......2d Glacial.......... Drift. } \\
\text { Aftonian Epoch.....1st inter-Glacial...Erosion. } \\
\text { Kansan Epoch......1st Glacial........Drift. } \\
\text { Ozarkian Epoch....pre-Glacial .........Erosion. }\end{array}$ \\
\hline
\end{tabular}

Lafayette Period..... Deposition.

Oscar H. Hershey.
[Note. The subdivisions of the Pleistocene period in the above table, except the last, are from Chamberlin's classification of the drift. The inter-glacial epoch between the Iowan and Wisconsin stages of glaciation has been provisionally named from the fossiliferous beds at Toronto, Canada, although it is considered far from certain that these strata belong to this epoch.

It is not customary to affix names to periods of erosion, although these are generally the longest and often the best marked divisions of geologic time. It has been suggested that it would be well to simply recognize the intervals of erosion, when encountered in any region, and wait until deposits occupying them have been discovered, before naming them. But in the case of the particular one under discussion, the conditions were such that no deposits contemporaneous with it are likely to be discovered. During the period of elevation which immediately succeeded on the Lafayette submergence the shore line was far beyond its present position, and the river alluvium and marine deposits of that epoch are buried under later formations and covered by the sea, where they can never be examined. Nor are there any correlative glacial deposits which could furnish a name to the epoch. The Ozarkian epoch as proposed is to terminate previous to the earliest Pleistocene glaciation of any portion of North America, except, perhaps, the far North. At present the Kansan epoch, which is to include the advance and retreat of the ice sheet which formed the so-called Kansan drift, is considered the first of the great glaciations. But if any decisive evidence of any previous distinct glaciation should be discovered it would constitute a new epoch and simply detract from the length of the Ozarkian epoch. The writer is of the opinion that the portion of the Quaternary era characterized by glacial conditions began at some time subsequent to the opening of the era, and it is to this distinctively pre-glacial portion that I wish to attach the name, Ozarkian epoch O. H. H.].

\section{ORGANIC MARKINGS IN LAKE SUPERIOR IRON ORES.}

A $\mathrm{T}$ the instance of Dr. Charles D. Walcott, Director U. S. Geological Survey, and with the kind permission of the editor of this paper, I beg to submit the following note, hoping that the subject may be brought to the notice of the officers of the U. S. Geological Survey, the Geological Surveys of Michigan and Wisconsin, etc., as well as that of all field workers among the rocks. of

Freeport, ILL. 
the iron-ore regions whose structural and paleontological geology in detail has yet to be unraveled, or is at present being worked up for publication, in this as well as in other countries.

I merely desire here and now to announce the discovery of traces of organic remains, made by me in fragments of iron ore from the Chapin mine, Iron Mountain, Menominee, Michigan, as well as possibly. from other mines on the same range or elsewhere in the Lake Superior region. It is hoped shortly to publish a much fuller account of my work in this connection, in another place.

During the period of $1890-93$, I collected a considerable number of specimens of iron ore from the ore piles on the docks at Erie, Pa., and was firmly of opinion that some of the markings upon them or in them were of organic origin, produced by animals of some kind; but being only an amateur geologist, I decided to submit the material to Prof. H. S. Williams, of New Haven, Conn., for examination. After seeing the specimens, Prof. Williams kindly wrote: "There are certainly some among them which resemble very strongly the trailings left by worms or crawling things on the sand."

The material was then forwarded to the U. S. National Museum, Washington, D. C., where Prof. Charles Schuchert, assistant curator of the Museum-Smithsonion Institution-examined them, and said: "The specimens of the Algonquin ores contain annelid trails."

Finally they were placed in the hands of Dr. Chas. D. Walcott for examination and he kindly reported as follows: "Most of the specimens from the Lake Superior region containing 'traces of organisms in Lake Superior iron ores' show only markings of mechanical origin. A few, numbers $10,14, \mathrm{~A}, \mathrm{E}$ and $\mathrm{G}$, appear to be casts of the trails of a small annelid and are, I think, organic. It is not possible to identify them with any described species. For convenience of reference they can be referred to the genus Planolites."

Prof. C. R. Van Hise, geologist in charge U. S. Geological Survey, Lake Superior Div., also saw the specimens and remarks that in his opinion the markings might possibly have been produced by some complex movement or movements, but that they are very peculiar, and in any ordinary case would be unhesitatingly accepted as organic. My long-since-formed opinion as to the organic origin of these markings having thus been confirmed by the highest authorities, this discovery will doubtless add a new phase to the question or controversy regarding the origin and age of these ake-region iron ores, and iron-bearing series of strata, and also should tend to excite renewed and closer investigation of the Huronian rocks in search of better 'fossils' than mine, which surely exist and will eventually be brought to light.

Those especially interested could, no doubt, see these specimens on application to Prof. Schuchert, at Washington, in whose care I propose to let them remain for the present.

W. S. GresLeY.

Erie, Pa.

\section{FOOD OF THE BARN OWL (STRIX PRATIN-} COLA).

IT is well known that birds of prey disgorge the indigestible portions of food, such as hair, bones and feathers. These are formed into balls, known as 'pellets' or 'rejects,' by the muscular action of the stomach and are regurgitated before a new supply of food is taken. The 'pellets' contain the skulls, teeth, and other parts of the victims, and furnish a perfect index to the food eaten. In a work on 'The Hawks and Owls of the United States,' published in 1893 , I recorded the results of the examination of 200 'pellets' or 'rejects' of the Barn 